\title{
Integrins: An Important Link between Angiogenesis, Inflammation and Eye Diseases
}

\author{
Małgorzata Mrugacz ${ }^{1, *(D)}$, Anna Bryl ${ }^{1}$, Mariusz Falkowski ${ }^{2}$ and Katarzyna Zorena ${ }^{3} \mathbb{D}$ \\ 1 Department of Ophthalmology and Eye Rehabilitation, Medical University of Bialystok, \\ 15-089 Bialystok, Poland; anna.bryl@umb.edu.pl \\ 2 Medical University of Bialystok, 15-089 Bialystok, Poland; mariusz.falkowski@adres.pl \\ 3 Department of Immunobiology and Environmental Microbiology, Medical University of Gdansk, \\ 80-211 Gdansk, Poland; katarzyna.zorena@gumed.edu.pl \\ * Correspondence: malgorzata.mrugacz@umb.edu.pl; Tel.: +48-502-650-858
}

Citation: Mrugacz, M.; Bryl, A.;

Falkowski, M.; Zorena, K. Integrins: An Important Link between

Angiogenesis, Inflammation and Eye Diseases. Cells 2021, 10, 1703 .

https://doi.org/10.3390/cells10071703

Academic Editor: Paola Bagnoli

Received: 10 May 2021

Accepted: 4 July 2021

Published: 6 July 2021

Publisher's Note: MDPI stays neutral with regard to jurisdictional claims in published maps and institutional affiliations.

Copyright: (C) 2021 by the authors Licensee MDPI, Basel, Switzerland. This article is an open access article distributed under the terms and conditions of the Creative Commons Attribution (CC BY) license (https:// creativecommons.org/licenses/by/ $4.0 /)$.

\begin{abstract}
Integrins belong to a group of cell adhesion molecules (CAMs) which is a large group of membrane-bound proteins. They are responsible for cell attachment to the extracellular matrix (ECM) and signal transduction from the ECM to the cells. Integrins take part in many other biological activities, such as extravasation, cell-to-cell adhesion, migration, cytokine activation and release, and act as receptors for some viruses, including severe acute respiratory syndrome-related coronavirus 2 (SARS-CoV-2). They play a pivotal role in cell proliferation, migration, apoptosis, tissue repair and are involved in the processes that are crucial to infection, inflammation and angiogenesis. Integrins have an important part in normal development and tissue homeostasis, and also in the development of pathological processes in the eye. This review presents the available evidence from human and animal research into integrin structure, classification, function and their role in inflammation, infection and angiogenesis in ocular diseases. Integrin receptors and ligands are clinically interesting and may be promising as new therapeutic targets in the treatment of some eye disorders.
\end{abstract}

Keywords: integrins; eye; cornea; dry eye disease; cataract; glaucoma; retina; age macular degeneration; diabetic retinopathy; retinopathy of prematurity; high myopia

\section{Introduction}

Integrins belong to a group of cell adhesion molecules (CAMs) which is a large group of membrane-bound proteins. They are involved both in cell attachment to the extracellular matrix (ECM) and in signal transduction from the ECM to the cells. They also take part in numerous biological activities, namely extravasation, cell-to-cell adhesion, cell migration, and function as receptors for certain viruses, including adenovirus, echovirus, hantavirus, foot-and-mouth disease, polio virus and severe acute respiratory syndrome-related coronavirus 2 (SARS-CoV-2). CAMs also include selectins, cadherins, immunoglobulin superfamily and other molecules, including CD44. Cell adhesion molecules are classified using the CD nomenclature (from 1 to 130) [1-3]. Integrins receive and transmit biochemical and mechanical signals through the cell membrane in both directions. Signals which develop inside the cell lead to conformational changes of the molecule and transmission of integrin into a state which enables ligand binding. The name "integrins" has been coined to denote the function they have maintaining a multicellular organism as a whole. They significantly affect the integrity of the cytoskeleton-ECM connections.

Knowing the structure, function and mechanism of integrin activation is very important, allowing detection of new compounds to be used in the case of inflammation, fighting thrombotic processes. It also enables searching for new possibilities in the case of venous embolism, neoplastic metastases and other diseases. 


\section{Integrin Structure}

Integrins are heterodimeric glycoproteins which serve a function of transmembrane receptors. They are composed of two chains, $\alpha$ and $\beta$, which can be joined together making 24 combinations of various heterodimers. These chains are noncovalently associated. The spatial structure of integrins resembles the human body [1-4]. The "head" is based on two "legs" which are changed into the transmembrane domain. Interactions between the $\alpha$ and $\beta$ subunits usually take place in the "head." The $\alpha$ chain is composed of a seven-bladed $\beta$ propeller joined with a thigh, calf- 1 and calf- 2 domains. This structure supports the integrin head. The last three or four blades of the $\beta$-propeller include domains that bind $\mathrm{Ca}^{2+}$. The $\beta$ chain is composed of $\beta I$, hybrid and PSI (plexin/semaphorin/integrin) domains and four cysteine-rich epidermal growth factor-like (EGF) modules. The $\beta$ I domain contains $\mathrm{Mg}^{2+}$. Divalent ions are essential for normal function of integrins. Each ion has a different function. $\mathrm{Mn}^{2+}$ and $\mathrm{Mg}^{2+}$ activate adhesion processes. $\mathrm{Ca}^{2+}$ ions, depending on concentration, may have an inhibitory or stimulatory effect. High $\mathrm{Ca}^{2+}$ concentration inhibits adhesion, whereas low $\mathrm{Ca}^{2+}$ concentration with optimal $\mathrm{Mg}^{2+}$ concentration stimulates binding of a ligand with an integrin [5].

\section{Integrin Activation}

Knowing the mechanism of integrin activation enables searching for new therapies of many diseases, e.g., cardiovascular diseases (venous emboli, myocardial infarctions), inflammatory diseases, allergies and metastatic processes. The presence and activity of integrins depend on numerous factors, which can be activators or inhibitors. These include hormones, cytokines, mediators of systemic inflammation, active components of the complement system, active oxygen species, endotoxins or pharmacological compounds. A change in the expression of integrin receptors usually takes place at the transcription level. Integrin activation leads to molecular transformation, which enables ligand binding [2].

Intracellular domains of both chains bind directly or indirectly with the cellular actinbased cytoskeleton $[1,6]$. Depending on the signal direction, integrin activation may take place in two ways: as outside-in signaling or inside-out signaling. In the case of outsidein signal transduction, ligand binding to extracellular domains of an integrin causes a shift of the subunit "head" segments, elongation of the integrin in the "knee" region and extending the whole structure. As a result, the domains forming the "legs" move apart. The transmembrane and cytoplasmic regions of both subunits are moved apart, too. This way, the integrin molecule is activated, showing a higher affinity to ligands. Then, clustering occurs, which in turn initiates adhesion processes between the cell and the extracellular matrix. In the case of inside-out activation, ligand conjugation is not necessary to activate an integrin. Such activation is mediated by intracellular proteins bound to the cytoplasmic skeleton: kindlin, talin and migflin [2].

Integrins occur in three various spatial configurations: closed, activated (extendedclosed) and active (extended-open) conformations. During transition from a closed to activated conformation, there occurs extension of the integrin between calf- 1 and thigh in the $\alpha$ subunit and between I-EGF- 1 and I-EGF- 2 in the $\beta$ subunit [7].

The integrin molecule is rich in cysteine residues which form disulfide bridges. A transition of an integrin from its inactive form to a form enabling ligand binding is preceded by reorganization of disulfide bonds inside the molecule. This reaction is catalyzed by protein disulfide isomerase (PDI). An example of PDI participation in integrin activation is the process of platelet aggregation. The PDI count is much lower in inactive platelets than during activation. Using anti-PDI antibodies, inhibition of blood platelet aggregation was observed. Other examples involve processes taking place in vascular endothelial cells. $\mathrm{Mn}^{2+}$ ions initiate formation of relatively stable complexes between the $\alpha_{V} \beta_{3}$ integrin and PDI [8]. 


\section{Integrin Classification}

Vertebrates have $18 \alpha$ and eight $\beta$ subunits, which form various heterodimers. Integrin heterodimers contain a number of combinations of $\alpha$ and $\beta$ subunits. Depending on the type of the ligand bound, integrins can be classified as collagen-binding integrins $\left(\alpha_{1} \beta_{1}, \alpha_{2} \beta_{1}, \alpha_{10} \beta_{1}, \alpha_{11} \beta_{1}\right)$, integrins recognizing the RGD motif (the triple amino acid sequence arginine-glycine-aspartic acid $\left(\alpha_{5} \beta_{1}, \alpha_{V} \beta_{1}, \alpha_{V} \beta_{3}, \alpha_{V} \beta_{5}, \alpha_{V} \beta_{6}, \alpha_{V} \beta_{8}, \alpha_{\mathrm{IIb}} \beta_{3}\right.$, $\left.\left.\alpha_{8} \beta_{1}\right)\right)$, laminin-binding integrins $\left(\alpha_{3} \beta_{1}, \alpha_{6} \beta_{1}, \alpha_{7} \beta_{1}, \alpha_{6} \beta_{4}\right)$ and leukocyte-binding integrins $\left(\alpha_{L} \beta_{2}, \alpha_{M} \beta_{2}, \alpha_{X} \beta_{2}, \alpha_{D} \beta_{2}\right)$. The $\beta_{2}$ integrin subunit (CD18) is able to couple to one of the $\alpha$ subunits $\left(\alpha_{\mathrm{L}}-\mathrm{CD} 11 \mathrm{a}, \alpha_{\mathrm{M}}-\mathrm{CD} 11 \mathrm{~b}, \alpha_{\mathrm{X}}-\mathrm{CD} 11 \mathrm{c}, \alpha_{\mathrm{D}}-\mathrm{CD} 11 \mathrm{~d}\right)$ to form lymphocyte function-associated antigen- 1 (LFA-1/ $\left.\alpha_{\mathrm{L}} \beta 2 / \mathrm{CD} 11 \mathrm{a} / \mathrm{CD} 18\right)$, macrophage- 1 antigen/complement receptor 3 (Mac1/CR3/ $\left.\alpha_{M} \beta 2 / C D 11 b / C D 18\right)$ and complement receptor 4 (p150,95/CR4/CD11c/CD18). The CD11a/CD18 is present mainly on all leukocytes, whereas CD11b/CD18, CD11c/CD18 and CD11d/CD18 are found on myeloid cells. The $\alpha_{\mathrm{M}} \beta_{2}$ integrin (also known as CR3, CD11b/CD18 or Mac-1) is expressed on phagocytic cells and engaged in the adhesion of leukocytes to the endothelium and microbial opsonization. Ligands for CR3 contain the complement component iC3b, the intercellular adhesion molecule (ICAM-1) and coagulation factors such as fibrinogen and factor X [1,2,9-11].

Another classification is based on the presence of the $\alpha \mathrm{I}$ domain. Belonging to one of the integrin families depends on the $\beta$ chain (with the most important $\beta_{1}, \beta_{2}$ and $\beta_{7}$ chains) combined with various $\alpha$ chains. Each of the $\beta$ subunits may form a heterodimeric receptor with various $\alpha$ subunits. An exception is the $\alpha_{V}$ subunit, which binds several different $\beta$ subunits, e.g., $\alpha_{V} \beta_{1}, \alpha_{V} \beta_{3}, \alpha_{V} \beta_{5}, \alpha_{V} \beta_{6}$. Since they may appear at $2-7$ weeks after lymphocyte stimulation, $\beta_{1}$ integrins are called very late antigens (VLA) or CD29. They participate in the binding of cells with the extracellular matrix. They bind laminin, fibronectin, vitronectin, collagen and other proteins of the extracellular matrix; therefore, they serve an important function in cell adhesion to the background. They occur on numerous cells of the immune system. They are absent on erythrocytes. Eosinophils show a presence of the $\alpha_{4} \beta_{1}$ and $\alpha_{6} \beta_{1}$ integrins, $\alpha_{4} \beta_{1}$ and $\alpha_{5} \beta_{1}$ basophils, $\alpha_{3} \beta_{1}, \alpha_{4} \beta_{1}$ and $\alpha_{5} \beta_{1}$ mastocytes. Neutrophils contain all the $\beta 1$ integrins, except for the $\alpha_{4} \beta_{1}$ integrin. On the other hand, $\beta_{2}$ integrins are present on cell membranes of all leukocyte populations. This subunit can be linked with one of the three $\alpha$ subunits which form the CD11a, CD11b, CD11c titer. The group of $\beta_{2}$ integrins contains the LFA-1, Mac-1 and GP-150/95 glycoproteins. The CD11a/CD18 integrin is called LFA-1 (leukocyte function-associated antigen) since these antigens are found only on leukocytes. The Mac-1 integrins occur in their inactive form on neutrophils, monocytes and NK cells. Activation and binding with ICAM-1 is caused by inflammatory factors. As a result, neutrophils are bound to endothelial cells [12,13].

Integrin ligands also include receptors, which belong to a family of immunoglobulinlike CAMs such as ICAM-1, vascular cell adhesion molecule 1 (VCAM 1). They occur, e.g., on the surface of endothelial cells. These connections are characterized by high bond strength. ICAM-1 is a ligand for the CD11a/CD18 integrin. ICAM-1 synthesis is triggered by TNF- $\alpha$, IL-1 and interferon gamma (IFN $\gamma$ ), endotoxin. ICAM- 2 binds to the CD11b/CD18 integrin. The CD11a/CD18 and CD11b/CD18 integrins play the most important role in the inflammatory process [14]. Integrins are also able to bind very different proteins of the extracellular matrix, e.g., fibronectin, fibrinogen, vitronectin, laminin, collagen, plasminogen, osteopontin, von Willebrand factor or sialoprotein of the matrix skeleton $[15,16]$. The alternative name for $\beta_{3}$ integrins is cytoadhesins. They play a major role in the adhesion and aggregation of blood platelets and in the formation of complexes. Recognizing the RGD sequence, they bind fibrinogen, vitronectin, fibronectin and von Willebrand factor. They include platelet adhesion gpIIb/IIIa (CD61/CD41) and receptor for vitronectin (CD61/CD51) which occurs on the endothelium and the macrophage cell membrane [17].

Integrin ligands may also include proteolysis-triggered endostatin (coming from type XVIII collagen), endorepellin and tumstatin. Moreover, integrins may also bind viper venom toxins called disintegrins, certain viruses and bacteria $[12,18]$. Various pathogens, 
e.g., echoviruses, adenoviruses, and herpesviruses use integrins to penetrate cells. Integrins may be receptors for SARS-CoV-2 and can be implicated in transmission and pathology of SARS-CoV-2 [3].

\section{Integrin Function}

Integrins play an important role in physiological and pathological processes, as well as in wound-healing processes. The specificity of the inflammatory process depends on adequate expression of adhesion molecules enabling leukocyte migration.

During inflammation, integrins enable white blood cells to cross the vascular wall. On the leukocyte membrane, $\beta_{2}$ integrins bind ICAM- 1 whereas $\alpha_{4} \beta_{1}$ and $\alpha_{4} \beta_{7}$ bind VCAM- 1 on endothelial cells $[19,20]$. The integrin $\alpha 4$ subunit can dimerize with either the $\beta_{1}$ or $\beta_{7}$ subunit to form the $\alpha_{4} \beta_{1}$ or $\alpha_{4} \beta_{7}$ integrin. During inflammation, $\alpha_{4} \beta_{1}$ promotes transendothelial lymphocyte migration into the inflamed tissue, whereas $\alpha_{4} \beta_{7}$ helps in lymphocyte migration into the intestinal mucosal lymphoid tissues [21]. In addition, the $\alpha_{4} \beta_{1}$ integrin can interact with vascular endothelial growth factor/VEGF receptor 2 (VEGF/VEGFR2) and/or contributes to VEGF functions in chronic lymphocytic leukemia (CLL) [22].

The adhesion and binding of leukocytes to the surface of the vascular endothelium result from the connection of the $\beta_{2}$ integrin of the leukocyte membrane with endothelial cells. A similar mechanism of adhesion to the vascular endothelium applies to circulating neoplastic cells. These interactions are essential for crossing the vascular barrier and forming metastasis. It has been demonstrated that the occurrence of $\beta_{4}$ and $\alpha_{6}$ integrins on the cells of squamous cell carcinoma is increased. The CD11b/CD18 integrin $\left(\beta_{2}\right)$ mediates responses to Gram-negative bacteria while interleukin 1 takes part in the migration of inflammatory cells. In the case of infection with Gram-positive bacteria, cells migrate via a CD11b/CD18-independent pathway [23-25].

Mutations in integrin subunits may cause various genetic diseases in humans. Three autosomal recessive diseases have been described: Glanzmann's thrombasthenia (mutations of the $\alpha_{\mathrm{IIb}}$ and $\beta_{3}$ integrins), leukocyte adhesion deficiency (LAD)—caused by point mutations or deletion of a gene in the $\beta_{2}$ integrin - characterized by hereditary deficiency syndrome [26] and vesicular epidermal necrolysis caused by mutation of the $\alpha_{6} \beta_{4}$ integrin $[27,28]$.

\section{Integrins and the Eye}

Integrins play a key role in normal eye development and maintaining tissue homeostasis, and also in the development of pathological processes, such as the healing process of the injuries of the cornea, keratoconus, allergic eye disease, keratitis, dry eye disease, eye infection in the course of COVID-19, lens opacification, glaucoma, diabetic retinopathy, axon degeneration in the optic nerve and scleral remodeling in high myopia (Table 1). Even a slight disorganization of eye tissues due to injury or other pathological disorders may dramatically affect normal vision. Learning about the regulation of integrin activity may serve as an important therapeutic goal.

Table 1. Integrins involved in the normal eye and eye diseases.

\begin{tabular}{ll}
\hline \multicolumn{1}{c}{ Part of the Eye/Disease } & \multicolumn{1}{c}{ Integrins } \\
\hline Cornea/ & $\alpha_{2} \beta_{1}, \alpha_{3} \beta_{1}, \alpha_{V} \beta_{5}, \alpha_{6} \beta_{4}$ \\
normal expression & $\alpha_{V} \beta_{6}$ \\
injury & $\alpha_{2}, \beta_{1}$ \\
healing process of the injury & $\alpha_{5} \beta_{1}$ \\
corneal lymphangiogenesis & $\alpha_{6} \beta_{4}$ \\
cicatricial pemphigoid & $\alpha_{V} \beta_{1}, \alpha_{V} \beta_{5}, \alpha_{3} \beta_{1}$ \\
epidemic keratoconjunctivitis & \\
\hline
\end{tabular}


Table 1. Cont.

\begin{tabular}{ll}
\hline \multicolumn{1}{c}{ Part of the Eye/Disease } & \multicolumn{1}{c}{ Integrins } \\
\hline $\begin{array}{l}\text { Conjunctiva and cornea/ } \\
\text { allergic conjunctivitis }\end{array}$ & $\alpha_{4} \beta_{1}, \alpha_{4} \beta_{7}, \alpha_{\mathrm{M}} \beta_{2}, \alpha_{\mathrm{L}} \beta_{2}$ \\
epidemic keratoconjunctivitis & $\alpha_{\mathrm{V}} \beta_{1}, \alpha_{\mathrm{V}} \beta_{5}, \alpha_{3} \beta_{1}$ \\
dry eye disease & $\alpha_{\mathrm{L}} \beta_{2}$ \\
COVID-19 & $\alpha_{\mathrm{V}} \beta_{1}, \alpha_{\mathrm{V}} \beta_{3}, \alpha_{\mathrm{V}} \beta_{5}, \alpha_{\mathrm{V}} \beta_{6}, \alpha_{\mathrm{V}} \beta_{8}$, \\
& $\alpha_{5} \beta_{1}, \alpha_{8} \beta_{1}, \alpha_{\mathrm{IIb}} \beta_{3}$ \\
\hline Lens/ & \\
normal development & $\alpha_{3} \beta_{1}, \alpha_{6} \beta_{1}, \alpha_{6} \beta_{4}, \alpha_{1} \beta_{1}, \alpha_{2} \beta_{1}$, \\
Cataract & $\alpha_{5} \beta_{1}, \alpha_{\mathrm{V}} \beta_{3}$ \\
\hline Trabecular meshwork or optic nerve head/ & $\alpha_{\mathrm{V}} \beta_{5}, \alpha_{\mathrm{V}} \beta_{6}, \alpha_{\mathrm{V}} \beta_{3}$ \\
Glaucoma & \\
\hline Retina/ & $\alpha_{\mathrm{V}} \beta_{3}$ \\
diabetic retinopathy & \\
retinopathy of prematurity & $\alpha_{\mathrm{L}} \beta_{2}$ \\
regeneration of the axons of the optic nerve & $\alpha_{\mathrm{V}} \beta_{3}$ \\
sclera/ & $\alpha_{9} \beta_{1}$ \\
myopia & $\alpha_{1}, \beta_{1}$ \\
\hline
\end{tabular}

\subsection{Integrins and Cornea}

The cornea consists of six layers: the epithelium, the epithelial basement membrane (EpBM) (the Bowman's layer), the stroma, Dua's layer and the endothelial cell basement membrane (Descemet's layer) and the endothelium [29]. The acellular layer of the ECM under EpBM is called the Bowman's layer [30]. The corneal epithelium shows the expression of several integrins. In the central cornea, $\alpha_{2} \beta_{1}, \alpha_{3} \beta_{1}, \alpha_{V} \beta_{5}$ and $\alpha_{6} \beta_{4}$ integrins are located within the epithelium, with the highest expression level in the basal cells. The $\alpha_{6} \beta_{4}$ integrin mediates adhesion to the EpBM using hemidesmosomes while $\alpha_{3} \beta_{1}$ and $\alpha_{V} \beta_{5}$ involve focal adhesions which are actin-based. The integrins expressed at the EpBM can mediate adhesion of corneal epithelial cells to fibronectins, vitronectin, collagens and laminins. Cells are less proliferative and adhesive to the basement membrane when integrin expression decreases [31].

The studies conducted have shown that in the healing process, skin fibroblasts use the $\alpha_{2}$ and $\beta_{1}$ integrins and the integrin $\alpha \mathrm{v}$ subunit. Removal of the $\beta_{1}$ integrin delays closure of skin wound [32]. In the case of corneal wound healing, neutrophils and lymphocytes are released from damaged corneal epithelium and then reach the injured site [33]. Migration of neutrophils depends on integrins. They migrate along the keratocyte network. These active keratocytes densify the region of stromal injuries [34]. The interactions between keratocytes/myofibroblasts and their integrins are involved in wound healing, and also in fibrosis which causes opacification of the cornea that may decrease visual acuity $[35,36]$. Fibrosis impacts the differentiation of stromal keratocytes into stress fibers containing myofibroblasts [37]. Stress fibers are formed by $\alpha$-smooth muscle actin (SMA), a specific marker of myofibroblasts that arrest normal transmission of light through the stroma and disturb vision [38]. The integrin $\alpha_{V} \beta_{6}$ is upregulated on injury [39] and is able to induce fibrosis as knocking out $\alpha_{V} \beta_{6}$ was found to decrease the level of SMA and thrombospondin 1 (TSP-1) activating TGF- $\beta$ at an early stage of the wound-healing process. This process may play an important role in the treatment of scars of the cornea [40]. In vitro studies revealed an increase in TGF- $\beta 1$ signaling and accelerated terminal differentiation of keratinocytes in mice [41]. The $\alpha_{6}$-encoding gene mutations and $\beta$ proteins expressed in the hemidesmosome lead to epidermolysis bullosa that causes ocular surface changes [42].

In addition, a recent study by Lin et al. has demonstrated that an extracellular matrix protein, transforming growth factor $\beta$-induced protein (TGFBIp), is increased in inflamed mouse corneas and may lead to lymphatic sprouting in corneal lymphangiogenesis (LA). 
The TGFBIp upregulation in a sutured cornea is correlated with infiltration of macrophages. TGFBIp stimulates migration, tube formation and adhesion of human lymphatic endothelial cells (HLECs) but has no impact on the proliferation of HLECs. In vitro, the TGFBIp's effect is mediated by the pathway of integrin $\alpha_{5} \beta_{1}$-FAK. Integrin $\alpha_{5} \beta_{1}$ blockade can significantly inhibit lymphatic sprouting induced by TGFBIp [43].

It should be noted that abnormal corneal LG is observed in several ocular diseases, e.g., in dry eye disease, transplant rejection, herpetic keratitis and eye allergy.

The interest in the $\alpha_{6} \beta_{4}$ increase revealed that patients who have cicatricial pemphigoid possess anti-integrin $\beta_{4}$ autoantibodies that bind to the basal surface of epithelial cells in the cornea and can lead to severe damage to the ocular surface and inflammation [44].

Weller et al. found out upregulation of integrins $\alpha_{1}, \alpha_{3}, \alpha_{4}, \alpha_{L}, \beta_{1}, \beta_{3}$ and $\beta_{4}$ in explanted endothelial cell-DM specimens from Fuchs' patients [45]. Fuchs' corneal dystrophy is a hereditary eye disease in which corneal endothelial degeneration and underlying Descemet membrane (DM) lead to corneal edema and haze. Fuchs' progression is characterized by DM thickening that is associated by increased EMT by the endothelial layer and ECM deposit formation. Further research is needed to assess the expression of integrins in the Fuchs' cornea to discover the impact of interactions between the corneal endothelium and DM on the pathogenesis and progression of this pathology.

\subsection{Integrins and Allergic Eye Diseases}

Integrins play an important role in allergic eye diseases, such as spring conjunctivitis and keratitis, atopic conjunctivitis and keratitis and giant papillary conjunctivitis. These diseases manifest themselves with lacrimation, itching, redness, burning and photophobia. An allergic reaction triggers release of mediators which cause migration of inflammatory cells (eosinophils, neutrophils, basophils and lymphocytes) to the reaction site. Cell adhesion molecules (selectins, integrins and immunoglobulins) are also part thereof. The first stage involves activation of $P$ - and E-selectins, integrins, such as $\alpha_{4} \beta_{1}, \alpha_{4} \beta_{7}, \alpha_{M} \beta_{2}, \alpha_{L} \beta_{2}$, and immunoglobulins (ICAM-1, ICAM-2, VCAM-1, VCAM-4, LFA-1), which ensure tight bond of eosinophils and basophils with vascular endothelial cells [46,47].

Integrins may affect keratitis which is a finding of epidemic keratoconjunctivitis (EKC) induced by six adenoviruses HAdV (HAdV-8, -19, -37, -53, -54 and -56). HAdV-37 interacts with integrin $\alpha_{V} \beta_{5}$ to enter non-ocular human cells. Storm et al. failed to find $\alpha_{V} \beta_{5}$ expression on human corneal epithelial cells and showed that integrins $\alpha_{V} \beta_{1}$ and $\alpha_{3} \beta_{1}$ are important for HAdV-37 infection of the corneal tissue [48].

\subsection{Integrins and Dry Eye Disease}

The prevalence of dry eye disease (DED) is high. DED is characterized by visual disturbance, symptoms of discomfort and tear film instability. It has been known that inflammation of the ocular surface and lacrimal gland is crucial in this disease [49]. The activation of $\mathrm{T}$ cells contributes to the inflammatory process and involves aggregation of several cell surface proteins between the antigen-presenting cells and $\mathrm{T}$ cells, including binding of the integrin LFA-1 to its cognate ligand, intercellular adhesion molecule 1 (ICAM-1). Importantly, LFA-1 and ICAM-1 interact in T cell adhesion and migration at inflammation sites. In recent years, numerous studies have been conducted on the regional use of the LFA-1 antagonist in dry eye syndrome. The studies revealed that the regional use of anti- LFA-1 led to significant improvement of symptoms of dry eye syndrome and suppression of inflammatory processes [50].

\subsection{Integrins and Eye Infection in the Course of COVID-19}

In 2019, there was the first report about a new viral infection in Wuhan, China. The new virus was designated as severe acute respiratory syndrome coronavirus 2 (SARS-CoV-2) that causes coronavirus disease 2019 (COVID-19). SARS-CoV-2 uses the angiotensin-converting enzyme 2 (ACE2) receptor for cell invasion, which is expressed in different tissues such 
as the lungs, the small intestine, the testicles, the kidneys, the brain and the eye [51]. ACE2 is the main cell surface receptor of SARS-CoV-2 that binds the virus' spike protein. Postmortem analysis of the eyes of patients with COVID-19 showed expression of ACE2 in the conjunctiva, limbus and cornea, especially in the superficial conjunctival and corneal epithelial surface. Surgical conjunctival specimens also revealed expression of ACE2 in the conjunctival epithelium, especially significant in the superficial epithelium. All postmortem eyes and surgical specimens also expressed transmembrane protease, serine 2 (TMPRSS2), a cell surface-associated enzyme that facilitates viral entry following binding of the viral spike protein to ACE2 [52]. These results suggest that ocular surface cells can be susceptible to infection by SARS-CoV-2. The study by Collin et al. indicates that local inflammation can enhance ACE2 expression, which explains overexpression of ACE2 in diseased conjunctiva. SARS-CoV-2 can also use integrins as cell receptors, binding to them through the RGD motif which is present in the receptor-binding domain in the spike protein of SARS-CoV2 [53]. The RGD motif is the minimal peptide sequence required for binding proteins of the integrin family [54] that is involved in the binding of human ACE2 [55]. Viral proteins with RGD motifs promote infection by binding integrin heterodimers including $\alpha_{V} \beta_{1}, \alpha_{V} \beta_{3}$, $\alpha_{V} \beta_{5}, \alpha_{V} \beta_{6}, \alpha_{V} \beta_{8}, \alpha_{5} \beta_{1}, \alpha_{8} \beta_{1}$ and $\alpha_{\mathrm{IIb}} \beta_{3}$ [54] activating transducing pathways involving phosphatidylinositol-3 kinase (PI-3K) or mitogen-activated protein kinase (MAPK), which promote virus entry and infection of the host cell [3]. Patients with COVID-19 may present ocular manifestations such as conjunctival congestion, chemosis, increased tearing, ocular pain and foreign body sensation [56,57].

\subsection{Integrins and the Lens}

Studies of the lens observed that the $\alpha_{3} \beta_{1}, \alpha_{6} \beta_{1}, \alpha_{6} \beta_{4}, \alpha_{1} \beta_{1}, \alpha_{2} \beta_{1}, \alpha_{5} \beta_{1}$ and $\alpha_{V} \beta_{3}$ integrins are expressed in the developing lens [58,59]. Altered integrin function is connected with the progression of fibrotic diseases of the lens. The $\alpha_{V} \beta_{5}, \alpha_{V} \beta_{6}$ and $\alpha_{V} \beta_{3}$ integrins play a role in the regulation of transforming growth factor $\beta$ (TGF- $\beta$ ) signaling pathways in posterior capsule opacification (PCO) and anterior subcapsular cataract (ASC). The regulation of TGF- $\beta$ signaling may prevent lens epithelial-to-mesenchymal transition (EMT) which leads to cataract $[60,61]$.

\subsection{Integrins and Glaucoma}

Glaucoma is a heterogeneous disease with alterations in the trabecular meshwork (TM) and the optic nerve head (ONH) [62]. The glaucoma-related phenotypic changes involve the actomyosin-based contractile properties of TM, ECM compliance and the types and quantity of proteins present in the ECM in the TM and the ONH. Integrin receptors are engaged in this bidirectional communication $[63,64]$.

The $\alpha_{V} \beta_{3}$ integrin plays a crucial role in the pathomechanism of glaucoma. The level of the $\alpha_{V}$ integrin was elevated in the layer of retinal ganglion cells (RGC) and in the glial cells of the nerve head after optic nerve crush in mice [65]. A study by Dickerson et al. [66] revealed downregulation of the $\alpha_{V}$ integrin unit expression by glucocorticoids. Other studies found an increase in the $\beta_{3}$ integrin unit expression in the TM $[63,67]$. The osteopontin-activated $\alpha_{V} \beta_{3}$ integrin signaling has been shown to control the eNOS/NO pathway that is involved in the outflow facility $[68,69]$.

\subsection{Integrins and the Retina}

Brem et al. studied expression of integrins from three different subfamilies in the human retina. Nine subunits showed unique distribution in the eye. Understanding the distribution of cell adhesion molecules in the retina will help to identify their function in the eye [70]. ICAM-1 is an adhesion molecule on endothelial cells and leukocytes which participates in the recruitment of leukocytes and inflammatory sites [71]. Increased levels of ICAM-1 expression occur in diabetic retinopathy [72]. A chronic inflammatory process is an important link in the development of type 2 diabetes. Leukocytes play an important role in the course of inflammatory processes at each stage of diabetes development, and 
also in diabetes complications in the form of micro- and macroangiopathy. As mentioned before, on the surface of leukocytes, there occur $\beta_{2}$ integrins which participate in adhesion to vascular walls by binding the ICAM- 1 molecule situated on the endothelium. Activation of leukocytes leads to increased expression of $\beta_{2}$ integrins. Therefore, it is believed that the level of $\beta_{2}$ integrin expression reflects the state of leukocyte activation. Enhanced leukocyte adhesion to vascular walls and production of factors with a potential cytotoxic effect (free radicals, TNF- $\alpha$ ) that destroy the vascular membrane (free radicals, metalloproteinases) and activate inflammatory response of vascular walls (IL-1, TNF- $\alpha$, arachidonic acid derivatives) and fibroblast proliferation may lead to accelerated development of atheromatous lesions and damage to small vessels [73]. Some studies indicate increased expression of $\beta_{2}$ integrins on leukocytes in diabetic patients [74]. The integrin beta subunit CD18 is increased in patients with diabetic retinopathy (DR) [75], and likewise significant increases in integrin alpha subunits CD11a [76] and CD11b [73] are found in these patients.

Retinopathy of prematurity (ROP), a two-phase disease of retinal vascular development, is caused by VEGF deregulation $[77,78]$. VEGF is downregulated in infants exposed to hyperoxia in phase 1, whereas in phase 2, VEGF is upregulated in relative/true hypoxia. There are several isoforms of VEGF, among which VEGFA165 predominates in the eye with multiple pro- and antiangiogenic splice variants [79]. A study conducted using a newborn mouse model of oxygen-induced retinopathy (OIR) showed that oxidative stress from fluctuating hyperoxia and hypoxia results in abnormal vascular development resembling human ROP [77]. An experimental study by Wilkinson-Berka et al. showed that the antagonist of the $\alpha_{V} \beta_{3}$ integrin attenuates angiogenesis in ROP and increases the overexpression of VEGF [80].

Within the adult central nervous system (CNS), tenascin C (TN-C) is the major ECM glycoprotein, upregulated at sites of damage in the brain, spinal cord and optic nerve. The integrin enabling cells to migrate on TN-C, $\alpha_{9} \beta_{1}$ is present in the CNS in the embryonic growth. Then, it is downregulated in adulthood and is not upregulated after injury. Integrins are transported into retinal ganglion cell axons in the retina, although this may be limited in the optic nerve, with the axons containing expressed integrins. Transduction of ganglion cells with the $\alpha_{9}$ integrin and kindlin-1 promotes regeneration of these axons, but the transport may be needed for regeneration of the remaining axons [81].

\subsection{Integrins and Myopia}

Integrins may impact scleral remodeling in high myopia leading to biomechanical weakening and continued scleral creep. An experimental study reported diminished levels of collagen-binding integrins $\alpha_{1}$ and $\beta_{1}$ during myopia progression [82]. Additionally, it was observed that basic fibroblast growth factor (bFGF) inhibited form deprivation myopia (FDM) in the experimental model; however, it was found to upregulate the levels of type 1 collagen, $\alpha_{2}$ integrin and $\beta_{1}$ integrin [83]. The latest research found all the known integrin alpha subunits except $\alpha_{D}$ and $\alpha_{E}$ in the scleral tissue of guinea pigs [84].

\subsection{Future Directions and Anti-Integrin Therapy}

The pathogenesis of many eye disorders characterized by pathological angiogenesis and inflammation involves deregulation of integrins. In these diseases, therapeutic procedures may directly target integrins or their ligands.

Recent investigations have emphasized an important role of the $\alpha_{4}$ integrin in allergic conjunctivitis and indicated a potential treatment of local allergy using DS-70, a novel $\alpha / \beta$ peptidomimetic $\alpha_{4}$ integrin antagonist, to inhibit the conjunctival infiltration of immune cells [85].

Integrin antagonists can improve signs and symptoms of patients suffering from dry eye disease, posterior capsular opacification, age-related macular degeneration, diabetic macular edema and vitreomacular traction. In the anterior segment, anti-integrin therapy can be employed to effectively treat DED. In this approach, lifitegrast, a small-molecule integrin antagonist, binds the CD11a subunit of LFA-1 and blocks the interaction between LFA-1 
and ICAM-1. In this way, it blocks the inflammatory pathways and inhibits subsequent T cell-mediated inflammation in DED [86,87]. An experimental study by Ecoiffier et al. demonstrated that local application of an anti-very late antigen 4 small-molecule antagonist (anti-VLA-4 sm) anti-integrin $\alpha_{4} \beta_{1}$ caused a reduction in dry eye signs and suppression of inflammatory changes such as a significant decrease in conjunctival $\mathrm{T}$ cell numbers and TNF- $\alpha$ transcript levels in the cornea and conjunctiva [46]. Local blockade of VLA-4 may be a new therapeutic approach in the treatment of clinical signs and inflammatory alterations connected with DED.

Therapeutic agents which are $\alpha_{V}$ integrin antagonists may be used to prevent posterior capsular opacification after cataract removal surgery. The research on mice revealed that cells deprived of the $\alpha_{V}$ integrin were transparent and showed no abnormalities [88].

Integrin peptide therapy for a posterior segment pathology significantly affects neovascular retinal diseases. This therapy targets integrin receptors that take part in cell signaling, regulation and construction of new and aberrant blood vessels and improves vision by regressing and inhibiting new blood vessel formation and by reducing retinal vascular leakage in the retina. Numerous clinical trials have been conducted to evaluate the efficacy of integrin antagonist therapy for age macular degeneration (AMD), proliferative diabetic retinopathy (PDR), macular edema, vitreomacular adhesion and traction. ALG-1001 is a novel $\alpha_{V} \beta_{3}, \alpha_{V} \beta_{5}$ and $\alpha_{5} \beta_{1}$ integrin inhibitor which has been demonstrated to affect both vitreolysis and angiogenesis. In the retina, integrin receptors $\alpha_{V} \beta_{3}, \alpha_{V} \beta_{5}$ and $\alpha_{5} \beta_{1}$ are associated with angiogenesis, both with choroidal angiogenesis found in dry and wet AMD and with preretinal angiogenesis connected with diabetic macular edema (DME) and retinal vein occlusion [89-91]. A phase Ilb clinical trial assessing the safety and efficacy of ALG-1001 in patients with vitreomacular adhesion (VMA) and vitreomacular traction (VMT) revealed good tolerance and lack of intraocular inflammation [92].

Integrin-targeted therapy is promising in ROP. Targeting $\alpha_{2} \beta_{1}$ integrin expression on endothelial cells reduces oxygen-induced retinopathy (OIR) [93]. The application of a non-peptide antagonist of the $\alpha_{V} \beta_{3}$ integrin, i.e., of 3-(3-(6-guanidino-1-oxoisoindolin2-yl)propanamido)-3-(pyridin-3yl)propanoic acid dihydrochloride, may inhibit retinal neovascularization [94]. There are interesting possibilities that endothelial $\alpha_{2} \beta_{1}$ may be a therapeutic target in pathological angiogenesis.

Summing up, the regulation of integrin expression is difficult since each cell adhesion molecule covers more than one type of cells and has several ligands which in combination result in various effects. In order to fully understand complex adhesion processes, it is necessary to conduct further studies and to search for factors that affect integrin expression. Thorough knowledge of the activity of integrins may contribute to the development of new diagnostic methods and immunotherapy of eye diseases.

Author Contributions: Conceptualization, M.M. and A.B.; writing-original draft preparation, M.M.; writing-review and editing, M.M., A.B., M.F. and K.Z. All authors have read and agreed to the published version of the manuscript.

Funding: This research received no external funding.

Institutional Review Board Statement: Not applicable.

Informed Consent Statement: Not applicable.

Data Availability Statement: Not applicable.

Conflicts of Interest: The authors declare no conflict of interest.

\section{References}

1. Mezu-Ndubuisi, O.J.; Maheshwari, A. The role of integrins in inflammation and angiogenesis. Pediatr. Res. 2020. [CrossRef] [PubMed]

2. Campbell, I.D.; Humphries, M.J. Integrin structure, activation, and interactions. Cold Spring Harb. Perspect. Biol. 2011,3 , a004994. [CrossRef] 
3. Sigrist, C.J.; Bridge, A.; Le Mercier, P. A potential role for integrins in host cell entry by SARS-CoV-2. Antiviral. Res. 2020, 177, 104759. [CrossRef]

4. $\quad$ Bednarczyk, M.; Stege, H.; Grabbe, S.; Bros, M. $\beta 2$ Integrins-Multi-Functional Leukocyte Receptors in Health and Disease. Int. J. Mol. Sci. 2020, 21, 1402. [CrossRef]

5. Mould, A.P.; Akiyam, S.K.; Humphries, M.J. Regulationof integrin $\alpha 5 \beta 1$-fobronectin interactions by divalent cations.Evidence for distinct chesses of binding sites for $\mathrm{Mn}^{2+}, \mathrm{Mg}^{2+}$ and $\mathrm{Ca}^{2+}$. J. Biol. Chem. 1995, 270, 26270-26277. [CrossRef] [PubMed]

6. Nair, K.S.; Naidoo, R.; Chetty, R. Expression of cell adhesion molecules in oesophageal carcinoma and its prognostic value. J. Clin. Pathol. 2005, 58, 343-351. [CrossRef]

7. Shi, M.; Foo, S.Y.; Tan, S.M. A structural hypothesis for the transition between bent and extended conformations of the leukocyte beta2 integrins. J. Biol. Chem. 2007, 282, 30198-30206. [CrossRef] [PubMed]

8. Swiatkowska, M.; Szymański, J.; Padula, G. Interaction and functional association of protein disulfide isomerase with alphaVbeta3 integrin on endothelial cells. FEBS J. 2008, 275, 1813-1823. [CrossRef] [PubMed]

9. Fagerholm, S.C.; Guenther, C.; Asens, M.L.; Savinko, T.; Uotila, L.M. Beta2-integrins and interacting proteins in leukocyte trafficking, immune suppression, and immunodeficiency disease. Front. Immunol. 2019, 10, 254. [CrossRef]

10. Bunting, M.; Harris, E.S.; McIntyre, T.M.; Prescott, S.M.; Zimmerman, G.A. Leukocyte adhesion deficiency syndromes: Adhesion and tethering defects involving beta 2 integrins and selectin ligands. Curr. Opin. Hematol. 2002, 9, 30-35. [CrossRef]

11. Yonekawa, K.; Harlan, J.M. Targeting leukocyte integrins in human diseases. J. Leukoc. Biol. 2005, 77, 129-140. [CrossRef]

12. Stewart, P.; Nemerov, G. Cell integrins:commonly used receptors for diverse viral pathogens. Trends Microbiol. 2007, 15, 500-507. [CrossRef]

13. Larsen, M.; Artym, V.; Green, J.A. The matrix reorganized: Extracellular matrix remogeling and integrin signaling. Curr. Opin. Cell Biol. 2006, 185, 463-471. [CrossRef] [PubMed]

14. Kourtzelis, I.; Mitroulis, I.; von Renesse, J. From leukocyte recruitment to resolution of inflammation: The cardinal role of integrins. J. Leukoc. Biol. 2017, 102, 677-683. [CrossRef] [PubMed]

15. Salazar-Noratto, G.E.; De Nijs, N.; Stevens, H.Y. Regional gene expression analysis of multiple tissues in an experimental animal model of post-traumatic osteoarthritis. Osteoarthr. Cartil. 2019, 27, 294-303. [CrossRef]

16. Miyamoto, S.; Katz, B.; Lafrenie, R. Fibronectin and integrins in cell adhesion, signaling and morphogenesis. Ann. N. Y. Acad. Sci. 1998, 857, 119-129. [CrossRef] [PubMed]

17. Tsai, W.B.; Grunkemeier, J.M.; McFarland, C.D. Platelet adhesion to polystyrene-based surfaces preadsorbed with plasmas selectively depleted in fibrinogen, fibronectin, vitronectin, or von Willebrand's factor. J. Biomed. Mater. Res. 2002, 60, 348-359. [CrossRef]

18. Hauck, C.R.; Agerer, F.; Muenzner, P. Cellular adhesion molecules as targets for bacterial infection. Eur. J. Cell Biol. 2006, 85, 235-242. [CrossRef] [PubMed]

19. Gorina, R.; Lyck, R.; Vestweber, D.; Engelhardt, B. $\beta 2$ integrin-mediated crawling on endothelial ICAM-1 and ICAM-2 is a prerequisite for transcellular neutrophil diapedesis across the inflamed blood-brain barrier. J. Immunol. 2014, 192, 324-337. [CrossRef]

20. Chang, A.C.; Chen, P.C.; Lin, Y.F.; Su, C.M.; Liu, J.F.; Lin, T.H.; Chuang, S.M.; Tang, C.H. Osteoblast-secreted WISP-1 promotes adherence of prostate cancer cells to bone via the VCAM-1/integrin $\alpha 4 \beta 1$ system. Cancer Lett. 2018, 426, 47-56. [CrossRef] [PubMed]

21. Sackstein, R. The lymphocyte homing receptors: Gatekeepers of the multistep paradigm. Curr. Opin. Hematol. 2005, 12, 444-450. [CrossRef]

22. Gutiérrez-González, A.; Aguilera-Montilla, N.; Ugarte-Berzal, E. $\alpha 4 \beta 1$ integrin associates with VEGFR2 in (CLL) cells and contributes to VEGF binding and intracellular signaling. Blood Adv. 2019, 3, 2144-2148. [CrossRef]

23. Ruoslahti, E. Integrins as signaling molecules and targets for tumor therapy. Kidney Int. 1997, 51, 1413-1417. [CrossRef]

24. Patriarca, C.; Alfano, R.M.; Sonnenberg, A. Integrin laminin receptor profile of pulmonary squamous cell adenocarcinomas. Hum. Pathol. 1998, 29, 1208-1215. [CrossRef]

25. Savoiu, P.; Trusoino, L.; Pepino, E. Expression and topography of integrins and basement membrane proteins in epidermal carcinomas. J. Investig. Dermatol. 1993, 101, 352-358. [CrossRef] [PubMed]

26. Hogg, N.; Bates, P.A. Genetic analysis of integrin function in man:LAD-1 and other Syndromes. Matrix Biol. 2000, 19, 211-222. [CrossRef]

27. Pulkkinen, L.; Kim, D.; Uitto, J. Epidermolysis bullosa with pyloric artresia: Novel mutations in the $\beta_{4}$ integrin gene (ITGB4). Am. J. Pathol. 1998, 152, 157-166.

28. Ruzzi, L.; Gagnoux-Palacios, L.; Pinola, M. A homozygous mutation in the integrin $\alpha 6$ gene in junctional epidermolysis bullosa with pyrolic atresia. J. Clin. Investig. 1997, 99, 2826-2831. [CrossRef]

29. Dua, H.S.; Faraj, L.A.; Said, D.G.; Gray, T.; Lowe, J. Human corneal anatomy redefined: A novel pre-Descemet's layer (Dua's layer). Ophthalmology 2013, 120, 1778-1785. [CrossRef] [PubMed]

30. Wilson, S.E. Bowman's layer in the cornea-structure and function and regeneration. Exp. Eye Res. 2020, 195, 108033. [CrossRef]

31. McKay, T.B.; Schlötzer-Schrehardt, U.; Pal-Ghosh, S.; Stepp, M.A. Integrin: Basement membrane adhesion by corneal epithelial and endothelial cells. Exp. Eye Res. 2020, 198, 108138. [CrossRef] 
32. Klenkler, B.; Sheardown, H. Growth factors in the anterior segment:role in tissue maintenance, wound healing and ocular pathology. Exp. Eye Res. 2004, 79, 677-688. [CrossRef]

33. Petrescu, M.S.; Larry, C.L.; Bowden, R.A. Neutrophil interactions with keratocytes during corneal epithelial wound healing:a role for CD18 integrins. Investig. Ophthalmol. Vis. Sci. 2007, 48, 5023-5029. [CrossRef]

34. Hanlon, S.D.; Smith, C.W.; Sauter, M.N. Integrin-dependent neutrophil migration in the injured mouse cornea. Exp. Eye Res. 2014, 120, 61-70. [CrossRef]

35. Wilson, S. Analysis of the keratocyte apoptosis, keratocyte proliferation, and myofibroblast transformation responses after photorefractive keratectomy and laser in situ keratomileusis. Trans. Am. Ophthalmol. Soc. 2002, 100, 411-433. [PubMed]

36. Sunil, K.; Hodge, W. The integrin needle in the stromal haystack:emerging role in corneal physiology and pathology. J. Cell Commun. Signal. 2014, 8, 113-124.

37. Wilson, S.E.; Mohan, R.R.; Hutcheon, A.E. Effect of ectopic epithelial tissue within the stroma on keratocyte apoptosis, mitosis, and myofibroblast transformation. Exp. Eye Res. 2003, 76, 193-201. [CrossRef]

38. Meek, K.M.; Knupp, C. Corneal structure and transparency. Prog. Ret. Eye Res. 2015, 49, 1-16. [CrossRef] [PubMed]

39. Puthawala, K.; Hadjiangelis, N.; Jacoby, S.C. Inhibition of integrin alpha(v)beta6, an activator of latent transforming growth factor-beta, prevents radiation-induced lung fibrosis. Am. J. Respir. Crit. Care Med. 2008, 177, 82-90. [CrossRef]

40. Wu, W.; Hutcheon, A.E.K.; Sriram, S. Initiation of fibrosis in the integrin Av $\beta 6$ knockout mice. Exp. Eye Res. 2019, 180, 23-28. [CrossRef]

41. Rodius, S.; Indra, G.; Thibault, C.; Pfister, V.; Georges-Labouesse, E. Loss of $\alpha 6$ integrins in keratinocytes leads to an increase in TGF $\beta$ and AP1 signaling and in expression of differentiation genes. J. Cell. Physiol. 2007, 212, 439-449. [CrossRef]

42. Jonsson, F.; Byström, B.; Davidson, A.E.; Backman, L.J.; Kellgren, T.G.; Tuft, S.J.; Koskela, T.; Rydén, P.; Sandgren, O.; Danielson, P.; et al. Mutations in Collagen, Type XVII, Alpha 1 (COL17A1) Cause Epithelial Recurrent Erosion Dystrophy (ERED). Hum. Mut. 2015, 36, 463-473. [CrossRef] [PubMed]

43. Lin, T.; Zhang, X.; Lu, Y.; Gong, L. TGFBIp mediates lymphatic sprouting in corneal lymphangiogenesis. J. Cell Mol. Med. 2019, 23, 7602-7616. [CrossRef]

44. Rashid, K.A.; Foster, C.S.; Ahmed, A.R. Identification of Epitopes Within Integrin $\beta 4$ for Binding of Auto-Antibodies in Ocular Cicatricial and Mucous Membrane Pemphigoid: Preliminary Report. Investig. Ophthalmol. Vis. Sci. 2013, 54, 7707-7716. [CrossRef] [PubMed]

45. Weller, J.M.; Zenkel, M.; Schlötzer-Schrehardt, U.; Bachmann, B.O.; Tourtas, T.; Kruse, F.E. Extracellular Matrix Alterations in Late-Onset Fuchs' Corneal Dystrophy. Investig. Ophthalmol. Vis. Sci. 2014, 55, 3700-3708. [CrossRef]

46. Ecoiffier, T.; Annan, E.L.; Rasnid, S. Modulation of integrin $\alpha 4 \beta 1$. Arch. Ophthalmol. 2008, 126, 1695-1699. [CrossRef] [PubMed]

47. Baiula, M.; Bedini, A.; Carbonari, G.; Dattoli, S.D.; Spampinato, S. Therapeutic targeting of eosinophil adhesion and accumulation in allergic conjunctivitis. Front. Pharmacol. 2012, 3, 203. [CrossRef]

48. Storm, R.J.; Persson, B.D.; Skalman, L.N. Human Adenovirus Type 37 Uses $\alpha_{V} \beta_{1}$ and $\alpha_{3} \beta_{1}$ Integrins for Infection of Human Corneal Cells. J. Virol. 2017, 91, e02019-16. [CrossRef] [PubMed]

49. Craig, J.P.; Nichols, K.K.; Akpek, E.K. TFOS DEWS II definition and classification report. Ocul. Surf. 2017, 15, 276-2830. [CrossRef]

50. Pflugfelder, S.C.; Stern, M.; Zhang, S. LFA-1/ICAM-1 Interaction as a Therapeutic Target in Dry Eye Disease. J. Ocul. Pharmacol. Ther. 2017, 33, 5-12. [CrossRef]

51. Lan, J.; Ge, J.; Yu, J.; Shan, S.; Zhou, H.; Fan, S.; Zhang, Q.; Shi, X.; Wang, Q.; Zhang, L.; et al. Crystal structure of the 2019-nCoV spike receptor-binding domain bound with the ACE2 receptor. bioRxiv 2020. [CrossRef]

52. Zhou, L.; Xu, Z.; Castiglione, G.M.; Soiberman, U.S.; Eberhart, C.G.; Duh, E.J. ACE2 and TMPRSS2 are expressed on the human ocular surface, suggesting susceptibility to SARS-CoV-2 infection. Ocul. Surf. 2020, 18, 537-544. [CrossRef] [PubMed]

53. Collin, J.; Queen, R.; Zerti, D.; Dorgau, B.; Georgiou, M.; Djidrovski, I.; Hussain, R.; Coxhead, J.M.; Joseph, A.; Rooney, P.; et al. Co-expression of SARS-CoV-2 entry genes in the superficial adult human conjunctival, limbal and corneal epithelium suggests an additional route of entry via the ocular surface. Ocul Surf. 2021, 19, 190-200. [CrossRef]

54. Hussein, H.A.M.; Walker, L.R.; Abdel-Raouf, U.M.; Desouky, S.A.; Montasser, A.K.M.; Akula, S.M. Beyond RGD: Virus interactions with integrins. Arch. Virol. 2015, 160, 2669-2681. [CrossRef]

55. Li, F.; Li, W.; Farzan, M.; Harrison, S.C. Structure of SARS coronavirus spike receptor-binding domain complexed with receptor. Science 2005, 309, 1864-1868. [CrossRef] [PubMed]

56. Wu, Z.; McGoogan, J.M. Characteristics of and important lessons from the coronavirus disease 2019 (COVID-19) outbreak in China: Summary of a report of 72,314 cases from the Chinese centers for disease control and prevention. JAMA 2020, 323, 1239. [CrossRef]

57. Chen, L.; Deng, C.; Chen, X. Ocular manifestations and clinical characteristics of 534 cases of COVID-19 in China: A cross-sectional study. medRxiv 2020. [CrossRef]

58. Walker, J.; Menko, A.S. Integrins in lens development and disease. Exp. Eye Res. 2009, 88, 216-225. [CrossRef] [PubMed]

59. Barbour, W.; Saika, S.; Miyamoto, T.; Ohkawa, K.; Utsunomiya, H.; Ohnishi, Y. Expression patterns of beta1-related alpha integrin subunits in murine lens during embryonic development and wound healing. Curr. Eye Res. 2004, 29, 1-10. [CrossRef] [PubMed]

60. Lovicu, F.J.; Shin, E.H.; McAvoy, J.W. Fibrosis in the lens. Sprouty regulation of TGF $\beta$-signaling prevents lens EMT leading to cataract. Exp. Eye Res. 2016, 142, 92-101. [CrossRef] 
61. Kubo, E.; Shibata, T.; Singh, D.P. Roles of TGF $\beta$ and FGF Signals in the Lens: Tropomyosin Regulation for Posterior Capsule Opacity. Int. J. Mol. Sci. 2018, 19, 3093. [CrossRef] [PubMed]

62. Wallace, D.M.; Pokrovskaya, O.; O'Brien, C.J. The function of matricellular proteins in the lamina cribosa and trabecular meshwork in glaucoma. J. Ocul. Pharmacol. Ther. 2015, 31, 386-395. [CrossRef] [PubMed]

63. Gagen, D.; Faralli, J.A.; Filla, M. The role of integrins in the trabecular meshwork. J. Ocul. Pharmacol. Ther. 2014, 30, 110-120. [CrossRef] [PubMed]

64. Filla, M.S.; Faralli, J.A.; Peotter, J.L. The role of integrins in glaucoma. Exp. Eye Res. 2017, 158, 24-136. [CrossRef]

65. Wang, A.; Yen, M.Y.; Hsu, W.M. Induction of vitronectin and integrin alpha in the retina after optic nerve injury. Mol. Vis. 2006, 12, 76-84.

66. Dickerson, J.E.; Steely, H.T.; English-Wright, S.L. The effect of dexamethasone on integrin and laminin expression in cultured human trabecular meshwork cells. Exp. Eye Res. 1998, 6, 731-738. [CrossRef]

67. Faralli, J.A.; Gagen, D.; Filla, M.S. Dexamethasone increases $\alpha \mathrm{v} \beta 3$ integrin expression and affinity through a calcineurin/NFAT pathway. BBA Mol. Cell Res. 2013, 1833, 3306-3313. [CrossRef] [PubMed]

68. Wang, Y.; Yan, W.; Lu, X.; Qian, C.; Zhang, J.; Li, P.; Shi, L.; Zhao, P.; Fu, Z.; Pu, P.; et al. Overexpression of osteopontin induces angiogenesis of endothelial progenitor cells via the $\alpha v \beta 3 / \mathrm{PI} 3 \mathrm{~K} / \mathrm{AKT} / \mathrm{eNOS} / \mathrm{NO}$ signaling pathway in glioma cells. Eur. J. Cell Biol. 2011, 90, 642-648. [CrossRef] [PubMed]

69. Chang, J.Y.; Stamer, W.D.; Bertrand, J.; Read, A.T.; Marando, C.M.; Ethier, C.R.; Overby, D.R. Role of nitric oxide in murine conventional outflow physiology. Am. J. Physiol. Cell Physiol. 2015, 309, C205-C214. [CrossRef]

70. Brem, R.B.; Robbins, S.G.; Wilson, D.J. Immunolocalization of integrins in the human retina. Investig. Ophthalmol. Vis. Sci. 1994, 35, 3466-3474.

71. Jose-Andres, C.; Okenka, G.; Kern, T.S.; Subauste, C.S. Identification of primary retinol cells and ex vivo detection of proinflammatory molecules using flow cytometry. Mol. Vis. 2009, 15, 1383-1389.

72. McLeod, D.S.; Lefer, D.J.; Merges, C. Enhanced expression of intracellular adhesion molecule-1 and P-selectin in the diabetic human retina and choroid. Am. J. Pathol. 1995, 147, 642-653.

73. Mastej, K.; Adamiec, R. Neutrophil surface expression of CD11b and CD62L in diabetic microangiopathy. Acta Diabetol. 2008, 45, 183-190. [CrossRef]

74. Fogelstrand, L.; Hulthe, J.; Hulten, L.M. Monocytic expression of CD14 and CD18, circulating adhesion molecules and inflammatory markers in women with diabetes mellitus and impaired glucose tolerance. Diabetology 2004, 47, 1948. [CrossRef] [PubMed]

75. Song, L.; Wang, S.L.; Hui, Y. Expression of CD18 on the neutrophils of patients with diabeticretinopathy. Graefe's Arch. Clin. Exp. Ophthalmol. 2007, 245, 24-31. [CrossRef] [PubMed]

76. Kretowski, A.; Myśliwiec, J.; Kinalska, I. The alterations of CD11A expression on peripheral blood lymphocytes/monocytes and CD62L expression on peripheral blood lymphocytes in Graves' disease and type 1 diabetes. Rocz. Akad. Med. Bialym. 1999, 44, 151-159.

77. Mezu-Ndubuisi, O.J. In vivo angiography quantifies oxygen-induced retinopathy vascular recovery. Optom. Vis. Sci. 2016, 93, 1268-1279. [CrossRef]

78. Mezu-Ndubuisi, O.J. Intravitreal delivery of VEGF-A165-loaded PLGA microparticles reduces retinal vaso-obliteration in an in vivo mouse model of retinopathy of prematurity. Curr. Eye Res. 2019, 44, 275-286. [CrossRef]

79. Zhao, M. Expression of pro-and anti-angiogenic isoforms of VEGF in the mouse model of oxygen-induced retinopathy. Exp. Eye Res. 2011, 93, 921-926. [CrossRef]

80. Wilkinson-Berka, J.L.; Jones, D.; Taylor, G.; Jaworski, K.; Kelly, D.J.; Ludbrook, S.B.; Willette, R.N.; Kumar, S.; Gilbert, R.E. SB-267268, a nonpeptidic antagonist of alpha(v)beta3 and alpha(v)beta5 integrins, reduces angiogenesis and VEGF expression in a mouse model of retinopathy of prematurity. Investig. Ophthalmol. Vis. Sci. 2006, 47, 1600-1605. [CrossRef]

81. Fawcett, J.W. An integrin approach to axon regeneration. Eye Lond. 2017, 31, 206-208. [CrossRef]

82. McBrien, N.A.; Metlapally, R.; Jobling, A.I. Expression of collagen-binding integrin receptors in the mammalian sclera and their regulation during the development of myopia. Investig. Ophthalmol. Vis. Sci. 2006, 47, 4674-4682. [CrossRef] [PubMed]

83. Tian, X.D.; Cheng, Y.X.; Liu, G.B. Expressions of type I collagen, alpha2 integrin and beta1 integrin in sclera of guinea pig with defocus myopia and inhibitory effects of bFGF on the formation of myopia. Int. J. Ophthalmol. 2013, 6, 54-58. [PubMed]

84. Wang, K.K.; Metlapally, R.; Wildsoet, C.F. Expression Profile of the Integrin Receptor Subunits in the Guinea Pig Sclera. Curr. Eye Res. 2017, 42, 857-863. [CrossRef] [PubMed]

85. Dattoli, S.D.; Baiula, M.; De Marco, R. DS-70, a novel and potent $\alpha_{4}$ integrin antagonist, is an effective treatment for experimental allergic conjunctivitis in guinea pigs. Br. J. Pharmacol. 2018, 175, 3891-3910. [CrossRef]

86. Perez, V.L.; Pflugfelder, S.C.; Zhang, S. Lifitegrast, a novel integrin antagonist for treatment of dry eye disease. Ocul. Surf. 2016, 14, 207-215. [CrossRef] [PubMed]

87. Nichols, K.K.; Donnenfeld, E.D.; Karpecki, P.M.; Hovanesian, J.A.; Raychaudhuri, A.; Shojaei, A.; Zhang, S. Safety and tolerability of lifitegrast ophthalmic solution 5.0\%: Pooled analysis of five randomized controlled trials in dry eye disease. Eur. J. Ophthalmol. 2019, 29, 394-401. [CrossRef] [PubMed]

88. Mamuya, F.A.; Wang, Y.; Roop, V.H. The roles of $\alpha \mathrm{V}$ integrins in lens EMT and posterior capsular opacification. J. Cell Mol. Med. 2014, 18, 656-670. [CrossRef] [PubMed] 
89. Guerrero-Narranjo, J.L. A Safety and Efficacy Study of ALG-1001 in Human Subjects with Wet Age-Related Macular Degeneration. ClinicalTrials.gov. U.S. National Institutes of Health. Available online: https:/ / www.clinicaltrials.gov/ct2/show/NCT01749891? term=ALG-1001\&rank=1 (accessed on 12 December 2017).

90. Karageozian, V. A Safety and Efficacy Study of Alg-1001 in Human Subjects with Symptomatic Focal Vitreomacular Adhesion. ClinicalTrials.gov. U.S. National Institutes of Health. Available online: https:/ / www.clinicaltrials.gov/ct2/show / NCT02153476? term=ALG-1001\&rank=2 (accessed on 22 December 2016).

91. Karageozian, V. Phase A 2 Randomized, Controlled, Double Masked, Multicenter Clinical Trial Designed to Evaluate the Safety and Exploratory Efficacy of Luminate®(ALG-1001) as Compared to Avastin®and Focal Laser Photocoagulation in the Treatment of Diabetic Macular Edema. ClinicalTrials.gov. U.S. National Institutes of Health. Available online: https: / / www.clinicaltrials.gov / ct2/show /NCT02348918?term=ALG-1001\&rank=4 (accessed on 2 January 2017).

92. Kuppermann, B.D. A Dual-Mechanism Drug for Vitreoretinal Diseases. Retina Today. Available online: http:/ / retinatoday.com/ pdfs/0715RT_Cover_Kupperman.pdf (accessed on 29 January 2017).

93. Madamanchi, A.; Capozzi, M.; Ling Genget, L. Mitigation of oxygen-induced retinopathy in $\alpha 2 \beta 1$ integrin-deficient mice. Investig. Ophthalmol. Vis. Sci. 2014, 55, 4338-4347. [CrossRef]

94. Li, Y.J.; Li, X.H.; Wang, L.F.; Kuang, X.; Hang, Z.X.; Deng, Y.; Du, J.R. Therapeutic efficacy of a novel non-peptide $\alpha v \beta 3$ integrin antagonist for pathological retinal angiogenesis in mice. Exp. Eye Res. 2014, 129, 119-126. [CrossRef] 